Acta Crystallographica Section C

Crystal Structure

Communications

ISSN 0108-2701

\section{Bis[(2-pyridyl)(2-pyridylamino)- methanolato]cobalt(III) perchlorate: a consequence of cobalt ion-assisted oxidative deamination of a tris(pyridyl)aminal ligand}

\author{
Harry Adams, ${ }^{\text {a* }}$ Musa S. Shongwe, ${ }^{\text {b }}$ Ibtisam Al-Bahri, ${ }^{\text {b }}$ \\ Eiman Al-Busaidi ${ }^{b}$ and Michael J. Morris ${ }^{a}$ \\ ${ }^{a}$ Department of Chemistry, University of Sheffield, Brook Hill, Sheffield S3 7HF, \\ England, and ${ }^{\mathbf{b}}$ Department of Chemistry, College of Science, Sultan Qaboos \\ University, PO Box 36, Al-Khod 123, Muscat, Oman \\ Correspondence e-mail: h.adams@sheffield.ac.uk
}

Received 14 September 2005

Accepted 19 October 2005

Online 11 November 2005

The title compound, $\left[\mathrm{Co}\left(\mathrm{C}_{11} \mathrm{H}_{10} \mathrm{~N}_{3} \mathrm{O}\right)_{2}\right] \mathrm{ClO}_{4}$, designated $\left[\mathrm{Co}\left(L_{2}\right)_{2}\right] \mathrm{ClO}_{4}$, was synthesized by reaction of $\mathrm{Co}^{\mathrm{II}}$ with two molar equivalents of (2-pyridyl)bis(2-pyridylamino)methane $\left(L_{1}\right)$ under ambient conditions, whereby the divalent metal ion was oxidized concomitantly with oxygenation and deamination of the aminal polydentate ligand to generate the tridentate ligand anion (2-pyridyl)(2-pyridylamino)methanolate, $L_{2}{ }^{-}$. In the X-ray crystal structure of the complex cation, $\left[\mathrm{Co}\left(L_{2}\right)_{2}\right]^{+}$, the two $L_{2}{ }^{-}$ligands are coordinated to the central cobalt(III) metal ion in a facial mode to afford a pseudooctahedral geometry. The four pyridyl $\mathrm{N}$ atoms constitute the equatorial plane on which the cobalt(III) ion lies; the methanolate $\mathrm{O}$ atoms occupy the axial positions.

\section{Comment}

One of the crucial requirements for a metal to act as an electron carrier at biochemical redox centres is the availability of at least two readily accessible stable oxidation states of the metal that differ by one unit. Hence, several of the first-row transition metals play major roles in a diverse range of enzymatic and electron-transfer processes in biological systems. Cobalt is well known for its role in the inorganic biochemistry of the cobalamins, rare examples of naturally occurring organometallic compounds (Cotton et al., 1999). At the centre of the coenzymes of the cobalamins, namely 5'-deoxyadenosylcobalamin (coenzyme $\mathrm{B}_{12}$ ) and methylcobalamin $\left(\mathrm{MeB}_{12}\right)$, cobalt participates in catalytic radical-induced 1,2rearrangement reactions and biomethylations, respectively (Lippard \& Berg, 1994; Bertini \& Luchinat, 1994; Kaim \& Schwederski, 1994). In the catalytic cycles of these processes, cobalt shuttles between the divalent and trivalent states, and in $\mathrm{MeB}_{12}$, the relatively uncommon +1 state is also utilized (Drennan et al., 1994; Kräutler \& Kratky, 1996).
The importance of low-spin cobalt(III) revolves around the kinetic inertness of its compounds, which has facilitated mechanistic studies in coordination chemistry. Virtually all octahedral cobalt(III) complexes are diamagnetic (configuration $t_{2 g}^{6}$ ), with the exception of $\left[\mathrm{CoF}_{6}\right]^{3-}$ and $\left[\mathrm{CoF}_{3}\left(\mathrm{H}_{2} \mathrm{O}\right)_{3}\right]$ (Cotton et al., 1999). Generally, in coordination chemistry, $\mathrm{Co}^{\mathrm{III}}$ is obtained from $\mathrm{Co}^{\mathrm{II}}$ by atmospheric or chemical oxidation (using oxidants such as $\mathrm{H}_{2} \mathrm{O}_{2}$ ). The title compound, (I), was synthesized by reaction of $\mathrm{Co}\left(\mathrm{ClO}_{4}\right)_{2} \cdot 6 \mathrm{H}_{2} \mathrm{O}$ with two molar equivalents of (2-pyridyl)bis(2-pyridylamino)methane $\left(L_{1}\right)$ (Galvez et al., 1986; Arulsamy \& Hodgson, 1994) in EtOH in the presence of molecular oxygen at room temperature (see scheme below). Compound (I) was also obtained from the template reaction of stoichiometric amounts of pyridine-2carbaldehyde, 2-aminopyridine and $\mathrm{Co}\left(\mathrm{ClO}_{4}\right)_{2} \cdot 6 \mathrm{H}_{2} \mathrm{O}$ in refluxing ethanol. Microanalyses $(\mathrm{C}, \mathrm{H}$ and $\mathrm{N}$ ) of a crystalline sample of (I) are consistent with the suggested chemical formulation of (I). The IR spectrum of this compound exhibits a sharp absorption at $3356 \mathrm{~cm}^{-1}$, confirming the presence of $\mathrm{NH}$ (secondary amine) in the $\mathrm{L}_{2}^{-}$ligand synthesized in situ. The aliphatic and aromatic $\nu(\mathrm{C}-\mathrm{H})$ absorptions occur at 2875 and $3080 \mathrm{~cm}^{-1}$, respectively. The pyridyl ring vibrations are indicated by the stretching frequencies in the range 1400$1620 \mathrm{~cm}^{-1}$. The uncoordinated perchlorate ion is characterized by an intense and broad absorption centred around $1090 \mathrm{~cm}^{-1}$ and a moderate and sharp band at $625 \mathrm{~cm}^{-1}$ (Nakamoto, 1997; Srinivasan et al., 2005).

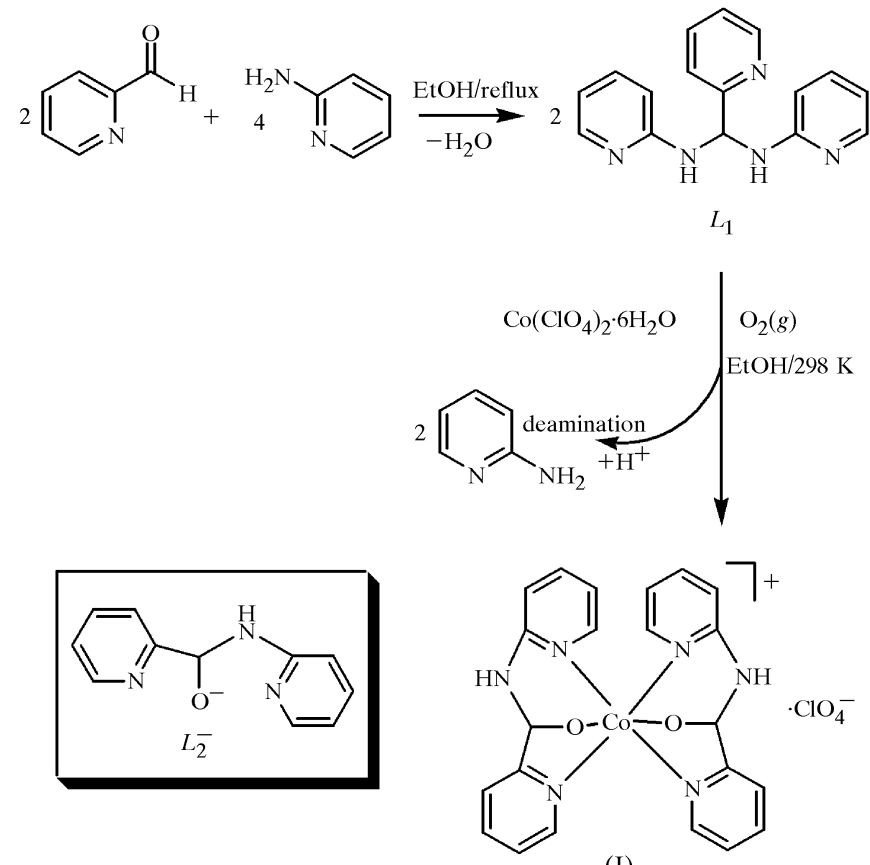

(I)

As observed previously for other octahedral $\mathrm{Co}^{\text {III }}$ complexes with $S=0$ (e.g. Mak et al., 1991; Emseis et al., 2004), the ${ }^{1} \mathrm{H}$ NMR spectrum of $\left[\mathrm{Co}\left(L_{2}\right)_{2}\right] \mathrm{ClO}_{4}$ in DMSO- $d_{6}$ exhibits sharp resonances, showing that (I) is indeed diamagnetic. A signal corresponding to the secondary amine $\mathrm{H}$ atom is observed at 5.52 p.p.m., and several multiplets in the chemical shift range 6.22-8.85 p.p.m. are associated with the pyridyl $\mathrm{H}$ atoms. Further evidence for the singlet ground state of 
compound (I) is provided by UV-visible spectroscopy. The electronic spectrum of (I) (Fig. 1) displays a shoulder at $398 \mathrm{~nm}$ [partially obscured by an intense intraligand $\pi \rightarrow \pi^{*}$ band at $\left.315 \mathrm{~nm}\left(\varepsilon=19500 M^{-1} \mathrm{~cm}^{-1}\right)\right]$ and a weak band at $514 \mathrm{~nm}\left(\varepsilon=80 \mathrm{M}^{-1} \mathrm{~cm}^{-1}\right)$, typical of low-spin $\mathrm{Co}^{\text {III }}$ complexes. Owing to the common chromophore $\mathrm{Co}^{\mathrm{III}} \mathrm{N}_{4} \mathrm{O}_{2}$, regardless of the differences in the other moieties present, the related $\mathrm{Co}^{\mathrm{III}}$ compounds carbonatobis[2-(2-pyridylamino)5,6-dihydro-4H-1,3-thiazine]cobalt(III) chloride (BarrosGarcía et al., 2004), (4,11-diacetato-1,4,8,11-tetraazabicyclo[6.6.2] hexadecane)cobalt(III) hexafluorophosphate (Lichty et al., 2004) and trans-bis(1,3-diamino-2-propanolato)-cobalt(III) perchlorate (Bruce, 2003) have electronic spectra that resemble that of compound (I), with two cobalt-based absorptions in each case at 395 (shoulder) and $532 \mathrm{~nm}, 355$ and $494 \mathrm{~nm}$, and 394 and $498 \mathrm{~nm}$, respectively. For all these aforementioned compounds, including (I), the two absorptions are attributable to ligand-field transitions; the higherenergy absorption represents the ${ }^{1} A_{1 g} \rightarrow{ }^{1} T_{2 g}$ transition, whereas the other is ascribed to the ${ }^{1} A_{1 g} \rightarrow{ }^{1} T_{1 \mathrm{~g}}$ transition. Commonly, the higher-energy $d-d$ band is masked by intra-

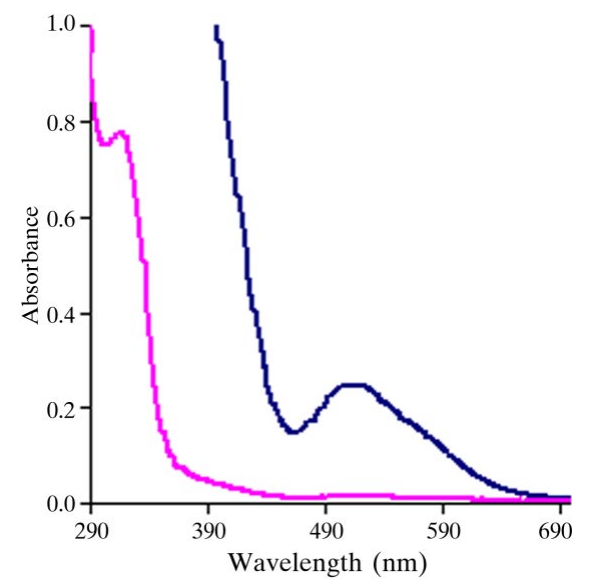

Figure 1

The electronic absorption spectrum of (I) in dimethyl sulfoxide (DMSO): $0.10 \mathrm{~m} M$ (lower line) and $3.0 \mathrm{~m} M$ (higher line).
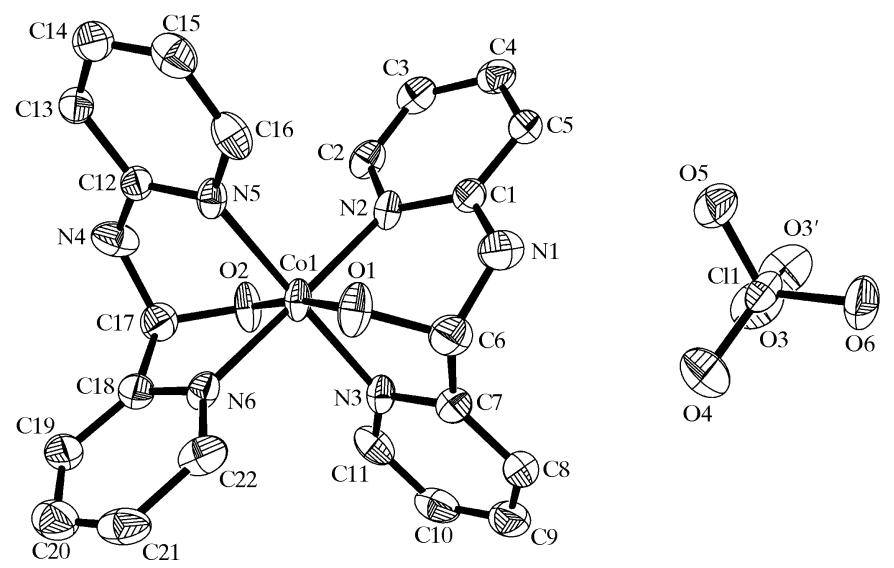

Figure 2

The crystal structure of (I), showing the mononuclear complex cation and the disordered perchlorate counter-ion. ligand $\pi \rightarrow \pi^{*}$ or LMCT bands (Djebbar-Sid et al., 2001; Tiliakos et al., 2001; Shongwe, Al-Hatmi et al., 2002; Saha et al., 2003; Barros-García et al., 2004). The pink-red colour of (I) is consistent with the electronic absorptions (Fig. 1).

Definitive evidence for the cobalt ion-assisted transformation of (2-pyridyl)bis(2-pyridylamino)methane $\left(L_{1}\right)$ to (2-pyridyl)bis(2-pyridylamino)methanolate $\left(L_{2}{ }^{-}\right)$in situ was provided by single-crystal X-ray crystallography. Compound (I) was isolated at room temperature as pink-red block-shaped crystals; it crystallized in the orthorhombic space group $P c a 2_{1}$. The crystal structure of (I) comprises a complex cation, $\left[\mathrm{Co}\left(L_{2}\right)_{2}\right]^{+}$, and a disordered perchlorate counter-anion (Fig. 2). The arrangement of the discrete mononuclear complex cations and counter-ions is shown in Fig. 3. Selected bond distances and angles are given in Table 1 . The crystal structure of the complex cation shows two tridentate (2pyridyl)bis(2-pyridylamino)methanolate ligands coordinated facially to the cobalt(III) ion to form a distorted octahedral geometry. The distortion, evidenced by deviations from idealized $O_{h}$ angles of $90^{\circ}$ and differences in bond distances in the coordination sphere, is a consequence of ligand constraints. The cobalt(III) ion resides on a pseudo-twofold axis of symmetry and on an equatorial plane formed by the pyridyl $\mathrm{N}$ atoms of the two ligands. The methanolate $\mathrm{O}$ atoms, in the axial positions $\left[\mathrm{O} 1-\mathrm{Co} 1-\mathrm{O} 2=172.61(19)^{\circ}\right]$, have stronger interactions with the central metal atom $\left[\mathrm{Co}^{\mathrm{III}}-\mathrm{O}_{\text {methanolate }}=\right.$ 1.893 (4) and 1.894 (4) $\AA$ ] than do the pyridyl $\mathrm{N}$ atoms (Table 1). The $\mathrm{Co}^{\mathrm{III}}-\mathrm{O}_{\text {methanolate }}$ distances compare favourably with the $\mathrm{Co}^{\mathrm{III}}-\mathrm{O}_{\text {propanolate }}[1.867$ (6) and 1.921 (5) $\AA$; Bruce, 2003], Co ${ }^{\mathrm{III}}-\mathrm{O}_{\text {carboxylate }}[1.882$ (6) and 1.916 (3) А; Shongwe, Al-Juma \& Fernandes, 2002; Lichty et al., 2004], $\mathrm{Co}^{\mathrm{III}}-\mathrm{O}_{\text {naphtholate }}[1.886$ (4)-1.9139 (17) Å; Kurahashi, 1976;

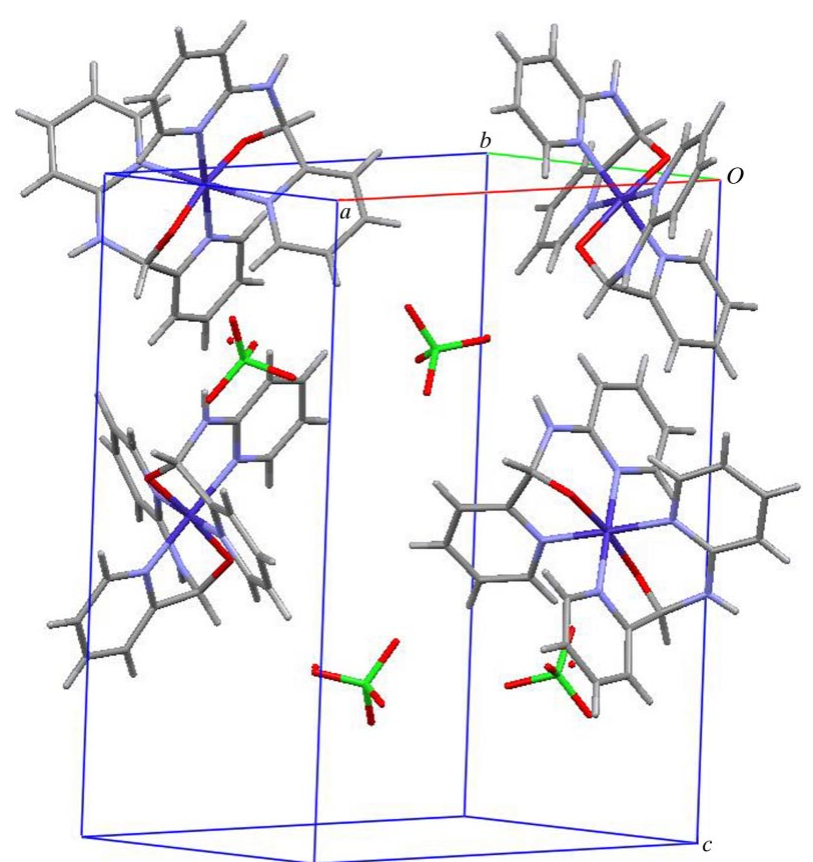

Figure 3

The packing of (I). 
Shongwe, Al-Juma \& Fernandes, 2002], $\mathrm{Co}^{\mathrm{III}}-\mathrm{O}_{\text {phenolate }}$ [1.862 (6)-1.928 (2) Å; Nassimbeni et al., 1976; Chen et al., 1991; Shongwe, Al-Hatmi et al., 2002] and $\mathrm{Co}^{\mathrm{III}}-\mathrm{O}_{\text {carbonate }}$ distances [1.907 (2) and 1.919 (2) §; Barros-García et al., 2004]. Likewise, the $\mathrm{Co}^{\mathrm{III}}-\mathrm{N}_{\text {pyridyl }}$ distances of (I) [1.917 (4)1.962 (4) ^] are normal (Tiliakos et al., 2001; Ghiladi et al., 2003; Barros-García et al., 2004; Stamatatos et al., 2005). Owing to steric constraints, the two $\mathrm{Co}^{\mathrm{III}}-\mathrm{N}_{\text {pyridyl }}$ distances (for each $\mathrm{L}_{2}{ }^{-}$ligand) in (I) are significantly different (by $0.044 \AA$ ). Similar behaviour has been demonstrated by the $\mathrm{Co}^{\mathrm{III}}$ complex of deprotonated $N, N^{\prime}$-bis(2-pyridyl)urea (Tiliakos et al., 2001).

The metal ion-assisted conversion of $L_{1}$ to $L_{2}{ }^{-}$has been demonstrated previously (Arulsamy \& Hodgson, 1994) using manganese(II) and iron(II) to form the $M^{\mathrm{III}}$ complexes $\left[\mathrm{Mn}\left(L_{2}\right)_{2}\right] \mathrm{ClO}_{4}$ and $\left[\mathrm{Fe}\left(L_{2}\right)_{2}\right] \mathrm{ClO}_{4}$, respectively, which are chemically isostructural with (I). It is noteworthy that in the case of the high-spin $\left(t_{2 g}^{3} e_{g}^{1}\right) \mathrm{Mn}^{\mathrm{III}}$ analogue, the equatorial bonds $\left(\mathrm{Mn}-\mathrm{N}_{\text {pyridyl }}\right)$ appear elongated in accordance with the Jahn-Teller effect (evident axial compression). In the reaction of $M^{\mathrm{II}}(M=\mathrm{Mn}, \mathrm{Fe}$ or $\mathrm{Co})$ with $L_{1}$ in air, oxygen is inserted into the ligand at the aliphatic $\mathrm{C}$ atom, causing deamination, as shown in the scheme. Cytochrome P450-dependent incorporation of $\mathrm{O}$ atoms from freely available molecular oxygen into organic chemical substrates occurs extensively in nature (Kaim \& Schwederski, 1994). In our system, we and others (Arulsamy \& Hodgson, 1994) have shown that a crucial requirement for the oxidative degradation of the aminal ligand $L_{1}$ is accessibility of a stable $M^{\mathrm{III}}$ oxidation state. Oxygenation of the ligand occurs in conjunction with oxidation of the $M^{\mathrm{II}}$ ions. In the case of $\mathrm{Ni}^{2+}$ (Arulsamy \& Hodgson, 1994) and $\mathrm{Cu}^{2+}$, the ligand $L_{1}$ remains intact during the reaction.

\section{Experimental}

$L_{1}$ was synthesized following literature procedures (Galvez et al., 1986; Arulsamy \& Hodgson, 1994). A solution of 2-aminopyridine $(4.7152 \mathrm{~g}, 0.050 \mathrm{~mol})$ in ethanol $(20 \mathrm{ml})$ was mixed with a solution of pyridine-2-carbaldehyde $(2.6780 \mathrm{~g}, 0.025 \mathrm{~mol})$ in ethanol $(20 \mathrm{ml})$ to give a light-yellow-brown solution. This solution was heated under reflux for $10 \mathrm{~h}$, during which time its colour remained essentially the same. Slow evaporation of the solution at room temperature over a period of $5 \mathrm{~d}$ gave colourless block-shaped crystals, which were washed several times with ice-cold ethanol and dried in air (yield 6.1012 g, 88.0\%; m.p. 389-391 K). Microanalysis found: C 69.40, H 5.47, N 25.15\%; calculated for $\mathrm{C}_{16} \mathrm{H}_{15} \mathrm{~N}_{5}\left(M_{r}=277.328\right): \mathrm{C} 69.30, \mathrm{H}$ 5.45, N 25.25\%; IR (KBr, cm $\left.{ }^{-1}\right): 3290,3245(\mathrm{~N}-\mathrm{H})$; UV-vis (DMSO, $\mathrm{nm}): 260\left(\varepsilon=15500 \mathrm{M}^{-1} \mathrm{~cm}^{-1}\right), 300\left(\varepsilon=9540 \mathrm{M}^{-1} \mathrm{~cm}^{-1}\right)$. For the preparation of $(\mathrm{I}), \mathrm{Co}\left(\mathrm{ClO}_{4}\right)_{2} \cdot 6 \mathrm{H}_{2} \mathrm{O}(0.1464 \mathrm{~g}, 0.40 \mathrm{mmol})$ was added to a solution of $L_{1}(0.2219 \mathrm{~g}, 0.80 \mathrm{mmol})$ in ethanol $(20 \mathrm{ml})$; an orange solution formed immediately and progressively darkened over time with continuous stirring at room temperature. After 5 min of stirring, the pink-red solution was filtered and kept at room temperature. After three days of slow evaporation, bright pink-red block-shaped crystals were deposited. After one week, the crystals had grown larger and become dark red. The crystals were washed with ice-cold ethanol and dried in air (yield $0.1375 \mathrm{~g}, 61.5 \%$ ). [ $\left.\operatorname{Co}\left(L_{2}\right)_{2}\right]$ $\mathrm{ClO}_{4}$ was also obtained in higher yield $(75 \%)$ from the template reaction of stoichiometric amounts $(0.20 \mathrm{mmol}$ scale based on the

$\mathrm{Co}^{\mathrm{II}}$ salt) of 2-aminopyridine, pyridine-2-carbaldehyde and Co$\left(\mathrm{ClO}_{4}\right)_{2} \cdot 6 \mathrm{H}_{2} \mathrm{O}$ (m.p. 514-515 K). Microanalysis found: $\mathrm{C} 47.20, \mathrm{H}$ 3.62, N 14.94\%; calculated for $\mathrm{C}_{22} \mathrm{H}_{20} \mathrm{ClCoN}_{6} \mathrm{O}_{6}\left(M_{r}=558.82\right): \mathrm{C}$ 47.29, H 3.61, N 15.04\%; IR $\left(\mathrm{KBr}, \mathrm{cm}^{-1}\right): 3356(\mathrm{~N}-\mathrm{H}), 1090,625$ $\left(\mathrm{ClO}_{4}{ }^{-}\right)$; UV-vis (DMSO, nm): $263\left(\varepsilon=19500 M^{-1} \mathrm{~cm}^{-1}\right), 315(\varepsilon=$ $\left.7800 \mathrm{M}^{-1} \mathrm{~cm}^{-1}\right), 398$ (shoulder), $514\left(\varepsilon=80 \mathrm{M}^{-1} \mathrm{~cm}^{-1}\right) ;{ }^{1} \mathrm{H}$ NMR (DMSO- $d_{6}$, p.p.m.): $\delta 5.52(d), 6.22-8.85(m)$.

\section{Crystal data}

$\left[\mathrm{Co}\left(\mathrm{C}_{11} \mathrm{H}_{10} \mathrm{~N}_{3} \mathrm{O}\right)_{2}\right] \mathrm{ClO}_{4}$

$M_{r}=558.82$

Orthorhombic, Pca2

$a=14.802(3) \AA$

$b=8.6144(18) \AA$

$c=17.832(4) \AA$

$V=2273.8(8) \AA^{3}$

$Z=4$

$D_{x}=1.632 \mathrm{Mg} \mathrm{m}^{-3}$

Data collection

Bruker SMART 1000

diffractometer

$\omega$ scans

Absorption correction: multi-scan (SADABS; Bruker, 1997)

$T_{\min }=0.756, T_{\max }=0.897$

23722 measured reflections

\section{Refinement}

Refinement on $F^{2}$

$R\left[F^{2}>2 \sigma\left(F^{2}\right)\right]=0.060$

$w R\left(F^{2}\right)=0.159$

$S=1.12$

5164 reflections

336 parameters

$\mathrm{H}$-atom parameters constrained

Table 1

Selected geometric parameters $\left(\AA{ }^{\circ}\right)$.

\begin{tabular}{lrlr}
\hline $\mathrm{Co} 1-\mathrm{O} 1$ & $1.893(4)$ & $\mathrm{Co} 1-\mathrm{N} 6$ & $1.930(4)$ \\
$\mathrm{Co} 1-\mathrm{O} 2$ & $1.894(4)$ & $\mathrm{Co} 1-\mathrm{N} 2$ & $1.959(4)$ \\
$\mathrm{Co1}-\mathrm{N} 3$ & $1.917(4)$ & $\mathrm{Co} 1-\mathrm{N} 5$ & $1.962(4)$ \\
& & & \\
$\mathrm{O} 1-\mathrm{Co} 1-\mathrm{O} 2$ & $172.61(19)$ & $\mathrm{N} 3-\mathrm{Co} 1-\mathrm{N} 2$ & $90.19(16)$ \\
$\mathrm{O} 1-\mathrm{Co} 1-\mathrm{N} 3$ & $83.59(16)$ & $\mathrm{N} 6-\mathrm{Co} 1-\mathrm{N} 2$ & $178.32(16)$ \\
$\mathrm{O} 2-\mathrm{Co} 1-\mathrm{N} 3$ & $90.82(17)$ & $\mathrm{O} 1-\mathrm{Co} 1-\mathrm{N} 5$ & $94.80(16)$ \\
$\mathrm{O} 1-\mathrm{Co} 1-\mathrm{N} 6$ & $91.29(16)$ & $\mathrm{O} 2-\mathrm{Co} 1-\mathrm{N} 5$ & $90.84(17)$ \\
$\mathrm{O} 2-\mathrm{Co} 1-\mathrm{N} 6$ & $83.94(15)$ & $\mathrm{N} 3-\mathrm{Co} 1-\mathrm{N} 5$ & $178.29(17)$ \\
$\mathrm{N} 3-\mathrm{Co} 1-\mathrm{N} 6$ & $90.73(16)$ & $\mathrm{N} 6-\mathrm{Co} 1-\mathrm{N} 5$ & $89.86(15)$ \\
$\mathrm{O} 1-\mathrm{Co} 1-\mathrm{N} 2$ & $90.21(16)$ & $\mathrm{N} 2-\mathrm{Co} 1-\mathrm{N} 5$ & $89.27(16)$ \\
$\mathrm{O} 2-\mathrm{Co} 1-\mathrm{N} 2$ & $94.64(15)$ & & \\
\hline
\end{tabular}

Attempts to solve the structure in space group Pcam with the central Co atom on a crystallographic twofold axis proved to be unsuccessful. Refinement and full convergence of the structure was achieved in the space group $P c a 2_{1}$. H atoms were positioned geometrically and refined with a riding model, with $\mathrm{C}-\mathrm{H}$ distances of $0.95-1.00 \AA, \mathrm{N}-\mathrm{H}$ distances of $0.88 \AA$, and $U_{\text {iso }}(\mathrm{H})$ values constrained to be 1.2 times $U_{\mathrm{eq}}$ of the carrier atom. The maximum residual electron density is $1.05 \AA$ from atom O2.

Data collection: SMART (Bruker, 1997); cell refinement: SMART; data reduction: SAINT (Bruker, 1997); program(s) used to solve structure: SHELXS97 (Sheldrick, 1990); program(s) used to refine structure: SHELXL97 (Sheldrick, 1997); molecular graphics: SHELXTL (Bruker, 1997); software used to prepare material for publication: SHELXTL. 
DOPSAR, Sultan Qaboos University, is gratefully acknowledged for financial support to MSS (grant No. IG/SCI/ CHEM/03/02).

Supplementary data for this paper are available from the IUCr electronic archives (Reference: FA1161). Services for accessing these data are described at the back of the journal.

\section{References}

Arulsamy, N. \& Hodgson, D. J. (1994). Inorg. Chem. 33, 4531-4536.

Barros-García, F. J., Bernalte-García, A., Higes-Rolando, F. J., Luna-Giles, F. \& Pedrero-Marín, R. (2004). Polyhedron, 23, 1453-1460.

Bertini, I. \& Luchinat, C. (1994). Bioinorganic Chemistry, edited by I. Bertini, H. B. Gray, S. J. Lippard \& J. S. Valentine, pp. 97-101. Sausalito: University Science Books.

Bruce, D. A. (2003). J. Chem. Crystallogr. 33, 569-574.

Bruker (1997). SMART, SAINT, SHELXTL and SADABS. Bruker AXS Inc., Madison, Wisconsin, USA.

Chen, M.-Q., Xu, J.-X. \& Zhang, H.-L. (1991). Хiegou Hиахие (J. Struct. Chem.), 10, 1-9.

Cotton, F. A., Wilkinson, G., Murillo, C. A. \& Bochmann, M. (1999). Advanced Inorganic Chemistry, 6th ed., pp. 814-835. New York: John Wiley \& Sons.

Djebbar-Sid, S., Benali-Baitich, O. \& Deloume J. P. (2001). J. Mol. Struct. 569, 121-128.

Drennan, C. L., Huang, S., Drummond, J. T., Matthews, R. G. \& Ludwig, M. L. (1994). Science, 266, 1669-1674.

Emseis, P., Failes, T. W., Hibbs, D. E., Leverett, P. \& Williams, P. A. (2004). Polyhedron, 23, 1749-1767.

Flack, H. D. (1983). Acta Cryst. A39, 876-881.

Galvez, E., Lorente, A., Iriepa, I., Florencio, F. \& García-Blanco, S. (1986). J. Mol. Struct. 142, 447-450.
Ghiladi, M., Gomez, J. T., Hazell, A., Kofod, P., Lumtscher, J. \& McKenzie, C. J. (2003). Dalton Trans. pp. 1320-1325.

Kaim, W. \& Schwederski, B. (1994). Bioinorganic Chemistry: Inorganic Elements in the Chemistry of Life, pp. 39-55, 112-118. Chichester: John Wiley \& Sons.

Kräutler, B. \& Kratky, C. (1996). Angew. Chem. Int. Ed. Engl. 35, 167170.

Kurahashi, M. (1976). Bull. Chem. Soc. Jpn, 49, 3053-3059.

Lichty, J., Allen, S. M., Grillo, A. I., Archibald, S. J. \& Hubin, T. J. (2004). Inorg. Chim. Acta, 357, 615-618.

Lippard, S. J. \& Berg, J. M. (1994). Principles of Inorganic Chemistry, pp. 336343. Mill Valley: University Science Books.

Mak, S.-T., Wong, W.-T., Yam, V. W.-W., Lai, T.-F. \& Che, C.-M. (1991). J. Chem. Soc. Dalton Trans. pp. 1915-1922.

Nakamoto, K. (1997). Infrared and Raman Spectra of Inorganic and Coordination Compounds, 5th ed., pp. 82-83. New York: John Wiley \& Sons.

Nassimbeni, L. R., Percy, G. C. \& Rodgers, A. L. (1976). Acta Cryst. B32, 12521256.

Saha, N. C., Butcher, R. J., Chaudhuri, S. \& Saha, N. (2003). Polyhedron, 22, 383-390.

Sheldrick, G. M. (1990). Acta Cryst. A46, 467-473.

Sheldrick, G. M. (1997). SHELXL97. University of Göttingen, Germany.

Shongwe, M. S., Al-Hatmi, S. K. M., Marques, H. M., Smith, R., Nukada, R. \& Mikuriya, M. (2002). J. Chem. Soc. Dalton Trans. pp. 4064-4069.

Shongwe, M. S., Al-Juma, S. A. \& Fernandes, M. A. (2002). Acta Cryst. E58, $\mathrm{m} 457-\mathrm{m} 459$.

Srinivasan, S., Annaraj, J. \& Athappan, P. R. (2005). J. Inorg. Biochem. 99, 876-882.

Stamatatos, T. C., Bell, A., Cooper, P., Terzis, A., Raptopoulou, C. P., Heath, S. L., Winpenny, R. E. P. \& Perlepes, S. P. (2005). Inorg. Chem. Commun. 8, 533-538.

Tiliakos, M., Cordopatis, P., Terzis, A., Raptopoulou, C. P., Perlepes, S. P. \& Manessi-Zoupa, E. (2001). Polyhedron, 20, 2203-2214. 